慶應義塾大学学術情報リポジトリ

Keio Associated Repository of Academic resouces

\begin{tabular}{|c|l|}
\hline Title & Japan's Security and the International Environment in the 1980s \\
\hline Sub Title & \\
\hline Author & 神谷, 不二(Kamiya, Fuji) \\
\hline Publisher & 慶應義塾大学法学部 \\
\hline Publication year & 1983 \\
\hline Jtitle & 慶應義塾創立一二五周年記念論文集 : 法学部政治学関係 (1983. 10),p.422-440 \\
\hline JaLC DOI & \multicolumn{1}{|l}{} \\
\hline Abstract & \\
\hline Notes & \\
\hline Genre & Book \\
\hline URL & https://koara.lib.keio.ac.jp/xoonips/modules/xoonips/detail.php?koara_id=BN01735019-0000000 \\
\hline
\end{tabular}

慶應義塾大学学術情報リポジトリ(KOARA)に掲載されているコンテンツの著作権は、それぞれの著作者、学会または出版社/発行者に帰属し、その権利は著作権法によって 保護されています。引用にあたっては、著作権法を遵守してご利用ください。

The copyrights of content available on the KeiO Associated Repository of Academic resources (KOARA) belong to the respective authors, academic societies, or publishers/issuers, and these rights are protected by the Japanese Copyright Act. When quoting the content, please follow the Japanese copyright act. 


\title{
Japan's Security and the International Environment in the 1980s
}

\author{
Fuji Kamiya
}

1. East Asia's Regional Security

2. A Perspective on the Soviet Union

3. Scenarios for Japanese Policy toward the Soviet Union

4. Recent Developments in Japanese Defense Policy

5. Defense Efforts in Fiscal 1983

\section{East Asia's Regional Security}

Fortunately it can be said today that the stability of the regional security of the Asian-Pacific basin surpasses that of the Middle East, South West Asia, Africa and even Europe.

Although Japan, just like other developed countries, has experienced various difficulties in the past ten years starting with the first oil crises, she has continued to show relatively better records than the other Western countries. In the political scene during this period, six consecutive changes of the cabinet made Japan appear unstable on the surface, but this was not actually so. Under the present thirty-five year old political situation, the Liberal Democratic Party dominates the Upper and the Lower Houses of the Diet with a stable majority and maintains a single party cabinet. The possibility that this situation will be fundamentally destroyed in the foreseeable future is close to nil.

Under these circumstances, Japan should be able to further contribute 
to the development and stability of East Asia more than it has been doing so far. In fact, there has been a tendency in some quarters in Asia in the past few years to worry about the possibility of Japan's becoming a great military power. However, as I will explain later in detail, Japan, in the framework of the "Peace Constitution" and the Japan-U.S. Security Pact after the Pacific War, only intends to make necessary adjustments in its defense force within the extent of self-defense. There exists a consensus amongst the public that Japan will strictly avoid maintaining military strength which should seem threatening to its neighbouring countries in the Asian-Pacific region.

China, after experiencing great domestic turmoil in the form of the Cultural Revolution in the dozen or so years since the latter $1960 \mathrm{~s}$, seems to have regained stability to some extent in the $1980 \mathrm{~s}$. Beijing is continuing to insist on the unification of Taiwan and is recently stressing the return of Hong Kong's sovereignty to China, but there are no symptoms showing attempts to realize these by taking drastic measures which might endanger the stability of East Asia. The economic and poiltical achievements of the ASEAN countries, on the other hand, have demonstrated that this loose form of regional integration is one of the most effective regionalisms the world has seen in the past years. Needless to say, the Oceanian region such as New Zealand and Australia remains quite stable.

As for the factors presently existing which might lead to instability and conflicts in East Asia, there are the following three. First, the situation in the Korean Peninsula should be cited. This peninsular has been left far behind from the tide of change in the world situation since $1950 \mathrm{~s}$, and the relationship between North and South Koreas remain to be governed by conflict and tension such as those which were seen in the cold war period. 
Nor has South Korea's attitude, referring to the "threat from the North" for acquiring aid and cooperation from the United States and Japan, changed over the past decades.

It is certain that the situation in the Korean Peninsula will be characterized by tension and instability. Nevertheless, in fact, we can find "unstable stability" or "stabilized instability" there. In the approximately one year and a half from the assassination of President Park in October, 1979 to the establishment of the so-called Fifth Republic in March. 1981, Korea suffered from serious domestic confusion and turmoil. If the North-South relation was truly so unstable and critical, this confusion of South Korea would have been a great opportunity for North Korea to take advantage of. Yet, as a matter of fact, no change occurred between North and South, and the confusion of the South was solved as a problem which involved the South only. It can be said that this course of events proves that the instability of the peninsula is in reality only a part of the unexpectedly stabilized instability.

The second region promoting instability in East Asia is the Indochina Peninsula. Here, the international civil war between the Heng Samrin regime which is backed up by the Vietnamese military power and the Democratic Kampuchea which consist of three groups including Shihanouk and the remnants of the Pol Pot administration, has been continuing for several years.

Many people say that this armed conflict in Kampuchea must be ended soon. However, this is only in theory. In actuality, most people probably do not desire the termination of this conflict. The ASEAN countries, including Thailand which borders Kampuchea, are in general anxious about the Vietnamese moves. Therefore, the situation by which Vietnam is caught 
up in the quagmire of Kampuchea is exactly what they wish, just as China wishes it. On the other hand, even though it is still recognized as the legitimate government by the United Nations, there is hardly any possibility that the Democratic Kampuchea will regain its powers and return as the master of Phnom Penh.

This labyrinth is functioning as a strange but effective deterrent against Vietnam and the Soviet Union backing it. In Japan, there is an old saying: "one illness ensures health." From time to time, a person who has no illness and who is too cofident of his health may easily fall ill due to negligence. In comparison, a person with a chronic disease will always be more careful than the others, so he can maintain his good health. The conflict in Kampuchea, from an objective point of view, may just be the "one illness" for the health of South East Asia and nothing more.

The third factor of instability in East Asia may be the Sino-Soviet relations. But, concerning this factor, the degree of danger has also decreased tremendously in the past years, and today, people's interests concentrate on how far the "reconciliation" will be advanced in the near future rather than on the "conflict" between the two countries.

The improvement or the normalization of the Sino-Soviet relations will further be advanced in the future. Nevertheless, it is almost inconceivable at the present that this trend should possibly result in the return to the alliance seen in 1950s. The first objective for the Soviet foreign policy today is the restoration of its relations with the United States, especially the search for compromise and agreement in the European INF and START. Also, the most important objectives for Chinese foreign policy are the enhancement of cooperation with Japan and the improvement in its relationship with the United States. The Sino-Soviet relations is not the number 


\section{Japan's Security and the International Environment (Kamiya)}

one goal for the Soviet Union nor for China, and it is only a supplementary goal in that they must strictly avoid giving adverse influence to U.S. relations and Japanese relations by placing too much at stake. Therefore, the fear that the conflict between the two countries will cause turmoil and instability in the entire East Asia is for the moment inconceivable, although the Sino-Soviet relations will be improved in the coming years on a limited scale.

\section{A Perspective on the Soviet Union}

Here let me offer some views on the Japanese perception of the Soviet Union and current Japanese-Soviet relations. First I will discuss some background factors, second I will look at the current situation, and third I will examine some policy options of the Japanese government.

In the past decades, the Japanese-Soviet relations have never smooth and the public feelings in Japan have never been warm toward the Soviet Union. The Soviet Union broke the Japanese-Soviet Neutrality Treaty and went to war against Japan immediately before its surrender in August of 1945. After the war it violated international law and humanity by hauling numerous Japanese who had lived in Manchuria to Siberia and placing them under long-term forced labour in harsh conditions. These actions solidified the anti-Soviet emotions of the Japanese people. Moreover, the continuation of illegal and illegitimate occupation of our Northern Territories, and the ruthless militaristic oppression of the satellite countries have made even the Japan Socialist Party (JSP) and the Japan Communist Party (JCP) change their original pro-Soviet stances to anti-Soviet ones.

In the 1970s, the Soviet Union achieved overall military "parity" with the United States and even surpassed the U.S. in some sectors, nuclear as 
well as conventional. In East Asia, during this period, the Soviet Union has been strengthening its military forces at a rapid pace, including more than 100 SS-20s, 70 Backfires, Minsk, and even deployed altogether one division of ground forces in our Northern Territories. The Soviet Union not only acquired naval and air bases in Vietnam, but also invaded Afghanistan at the end of 1979 .

These factors all contribute to the consistent showing in all public opinion polls that the Soviet Union is the least liked foreign country. Only two percent reply that they like the Soviet Union and this situation is unlikely to change in the foreseeable future. Nevertheless, these attitudes are not translated into bellicose feelings toward the Soviet Union. After the war, passivist sentiments ran extremely deeply in Japan, and a consequence is a certain public idealism that seeks avoidance of foreign entanglements. For the Japanese whose attitudes toward military power in the postwar period reflect a curious mixture of antipathy and indifference, the Soviet threat is only an indirect psychological threat rather than a direct military threat.

Also, there is in Japan more of a tendency to balance their military power against their economic and political weaknesses in our overall assessment of the Soviet Union and how we should respond to it. The Japanese basically think about security in terms of "comprehensive security," wellbalancing both military and non-military aspects. If we judge the Soviet Union "comprehensively," the vulnerability of its national power is evident in the non-military domain where Japan excels. Because of this, no matter how powerful the Soviet Union is militarily, the Japanese tend to discount overall Soviet power and even be contemptuous of it. And, Japan tends to underevaluate the efforts of the United States to counter the Soviet power 
simply by military means.

Thus, American calls for a common or joint strategy vis-a-vis the Soviet Union does not receive an adequately positive reaction among the Japanese in general.

On the other hand, I have to describe another aspect where there has been a shift in Japanese attitudes toward the Soviet Union in recent years. The Japanese are paying greater attention to the fact that Soviet military expenditure has been some fifteen times that of Japan for many years while the GNP of the two countries are almost equal. There is also increased awareness of the Soviet Union's accelerated expansion of its sphere of influence as evidenced in Vietnam, Angola, Ethiopia, Afghanistan, and so on.

Since the late 1970s there has been a steady, though gradual, strengthening of Japan-U.S. relations and a greater willingness on the part of Japanese governments to emphasize Japan's political solidarity with the Western world as part of its larger burden-sharing of international responsibilities. At the same time, since 1982, Japan has set February 7 th as the "Day of the Northern Territories," and representatives of all political parties from the Liberal Democratic Party (LDP) to the JCP attended a national convention on that day, last year and this year, demanding the reversion of the territories.

Now, Prime Minister Nakasone, who came to power in November last year (1982), tried to establish, through his meeting with President Reagan this January, the basic policies of strengthening Japan-U.S. alliance and stepping up Japan's defense efforts. This was warmly welcomed in the United States, and also, at first, in the Japanese domestic scene, there was sympathy with his efforts to speak in a straightforward manner about defense issues and to solidify the Japan-U.S. security system. 


\section{Scenarios for Japanese Policy toward the Soviet Union}

This leads to one possible scenario for future Japanese policy, that is, reinforced solidarity with the United States and a confrontationist attitude toward the Soviet Union. This policy does have overall advantages in terms of our relations with the United States, which is the most important politlcal and economic partner of Japan. It, however, also has serious liabilities.

The biggest of these is that it would not be supported by a broad enough base of Japanese public opinion. This is evident from the media and public reaction to Mr. Nakasone's emphasis on the Soviet threat after he came home from the United States. When Nakasone had likened Japan to an "unsinkable aircraft carrier" in the strategy toward the Soviet Union and also emphasized the poerational concept of "blockade of the three straits" which are the exits from the Sea of Japan to the outer ocean, the media and the Diet in Japan expressed anxiety and criticism, affecting the public opinion.

As a result, three public opinion polls, released by the NHK (Japan Broadcasting Corporation) on February 16th, the Asahi Shinbun on the 19th, and the Yomiuri Shinbun on the 23rd, showed fairly strong public dissatisfaction with his foreign policy stance and demonstrated that nonsupport considerably exceeded support for the Nakasone administration. Even within the LDP, at least for this current year during which the unified local election had been planned for April, the House of Councillors election of June, and depending on circumstances, probably a House of Representatives election, it was reported that more moderation was asked for in the Prime Minister's statements on defense issues. I might add that 
there are some elements within the LDP who are blaming the party's defeat in the Hokkaido gubernatorial election last week (April 10, 1983) to a Socialist candidate as a result of public dissatisfaction with the Nakasone defense statements, although many other factors were undoubtedly also involved in that race.

In other words, a confrontationist attitude could invite a public backlash and jeopardize the political position of those in Japan most concerned about the Soviet threat.

A second possible option for Japanese policy would be a stronger effort to separate political and economic relations. Tokyo upheld the principle of the separation of politics and economics vis-a-vis Beijing for long time until the normalization of relations in 1972, whereas since there is a territorial question between Japan and the Soviet Union, Tokyo has refused this principle, although Moscow has asserted it. And, Tokyo has maintained the position that it will continue to turn down Moscow's request to expand the Japan-Soviet economic cooperation, including Siberian development, unless Moscow yields in political matters such as the Northern Territories and Afghanistan. Japan cannot compromise the territorial question with the Soviet Union. In this connection, politics has priority over economics.

I believe that this governmental position is and will continue to be supported by the majority of the nation, but it is, on the other hand, also true that the separation of politics and economics remain popular with some Japanese, particularly with some business groups. Recently, in fact, there seems to be another upsurge in business interest in Siberia, partly stimulated by the world recession and fear of protectionism in major Japanese markets. Some of the Japanese businessmen have also been resentful of 
the trade opportunities lost because of Japan's acceptance of the U.S. sanction policy, while much of this business seems to have gone to European countries. A February Chamber of Commerce delegation to Moscow numbered 250 businessmen from many influential companies as well as small and medium business, the largest and most high-powered business delegation ever sent from Japan to any foreign country. The Foreign Ministry, on that occasion, cautioned the business leaders not to be too optimistic in view of the sensitive political relationship, but clearly business interest in the Soviet Union may represent a powerful force behind the separation of economics and politics.

The problem with this option is that it can be damaging in terms of Japanese alliance relationship. It can also encourage political adventurism on the part of the Soviet Union because it would appear to have no economic costs. More foundamentally, perhaps, Japan has simply grown too large to separate economics from politics. A major world economic power, Japan's economic relations with other countries do have political implications.

Maintaining some economic and other ties open to the Soviet Union, that is, keeping channels of communication and exchange open, could be useful in a time of increased political tensions, if done in a prudent way. This leads to a middle course that is a balanced response which recognizes realistically the Soviet threat, with due cognizance of alliance relationships, but which does not attempt to needlessly isolate or provoke the Soviet Union. We need a "carrot and stick" approach to counter the challenge of the Soviet Union.

There is general acceptance with in informed government and private circles that the Soviet threat has increased. This does suggest a strong 


\section{Japan's Security and the International Environment (Kamiya)}

need to reinforce a coordination in strategies among the Western countries. It certainly undermines our position when there are open disagreements among allies and friends on trade sanctions and arms control policies.

Japan would like to find some appropriate means and forum for discussing trade and political questions relating to the Soviet Union with its allies and friends, not just the United States, but also the European and Asian-Pacific countries.

There is more interest in Japan, although still relatively specialized circles, of current developments in nuclear arms control negotiations between the United States and the Soviet Union. Japan realizes that it does have a stake in the INF discussion; it does not want missiles now directed toward Europe to be simply redirected toward Asian targets. At the same time, there is a certain unhappiness with what appears to be too inflexible a position by the United States. Therefore, there is a need for broaderbased discussions of these issues as well.

To summarize, Japan does not regard itself as a major target of current Soviet interest or threat, but it is increasingly concerned about the Soviet forces in East Asia, about current developments in U.S. -Soviet and SinoSoviet relations, and about appropriate Western responses. While a strongly confrontationist policy is not likely for domestic political reasons to be pursued, Japan will probably continue to emphasize its solidarity with its allies and friends. Japan's relations with the Soviet Union cannot be divorced from its relations with the United States, nor can its economic ties with the Soviet Union stand apart from the current political tensions.

\section{Recent Developments in Japanese Defense Policy}

Japanese defense policy has recently become targets of discussions in 
Changes in Japan's Defense-Related Expenditures (After 1965)

\begin{tabular}{|c|c|c|c|c|c|}
\hline FY & $\begin{array}{l}\text { Defense-Relate } \\
\text { (First Stag } \\
\text { (Unit } 100 \mathrm{mil} . \\
\text { yen) }\end{array}$ & $\begin{array}{l}\text { Expenditure } \\
\text { Budget) } \\
\text { (Unit } 1 \mathrm{mil} . \\
\text { dols.) }\end{array}$ & $\begin{array}{l}\text { Rate of } \\
\text { increase over } \\
\text { previous year } \\
(\%)\end{array}$ & $\begin{array}{l}\text { Proportion } \\
\text { to } \\
\text { GNP } \\
(\%)\end{array}$ & $\begin{array}{l}\text { Proportion } \\
\text { to expenditure } \\
\text { in gen. account } \\
(\%)\end{array}$ \\
\hline '65 & 3,014 & 837 & 9.6 & 1.07 & 8.24 \\
\hline '66 & 3,407 & 946 & 11.8 & 1.10 & 7.90 \\
\hline '67 & 3,809 & 1,058 & 11.8 & 0.93 & 7.69 \\
\hline '68 & 4,221 & 1,173 & 10.8 & 0.88 & 7.25 \\
\hline 69 & 4,838 & 1,344 & 14.6 & 0.34 & 7.18 \\
\hline '70 & 5,695 & 1,582 & 17.7 & 0.79 & 7.16 \\
\hline '71 & 6,709 & 1,864 & 17.8 & 0.80 & 7.13 \\
\hline '72 & 8,002 & 2,598 & 19.3 & 0.88 & 6.98 \\
\hline '73 & 9,355 & 3,037 & 16.9 & 0.85 & 6.55 \\
\hline$' 74$ & 10,930 & 3,549 & 16.8 & 0.83 & 6.39 \\
\hline '75 & 13,273 & 4,309 & 21.4 & 0.84 & 6.23 \\
\hline '76 & 15,124 & 4,910 & 13.9 & 0.905 & 6.22 \\
\hline$' 77$ & 16,966 & 5,489 & 11.8 & 0.88 & 5.93 \\
\hline '78 & 19,010 & 7,256 & 12.4 & 0.90 & 5.54 \\
\hline '79 & 20,945 & 10,741 & 10.2 & 0.90 & 9.43 \\
\hline '82 & 25,861 & 11,293 & 7.754 & 0.93 & 5.21 \\
\hline '83 & 27,542 & 11,150 & 6.50 & 0.98 & 5.47 \\
\hline
\end{tabular}

Notes: (1) Dollar exchange rate until FY '71: 1 dol. $=360$ yen, FY '72-'77. 308 yen, FY '78: 262yen, FY '79: 195 yen, FY '80: 225 yen, FY '81: 217 yen, FY '82: 229 yen, FY '83: 247 yen. Moreover, if we convert the defense expenditure of FY ' 82 and ' 83 into U.S. dollar by the average exchange rate of January (for FY ' 83 , the rate of $1 / 4$ ), respective expenditure will be 11,465 million dollars and 11,944 million dollars.

(2) The proportion to GNP is the proportion to the anticipated GNP. 
various spheres inside and outside the country. From the one extreme, it is criticized as being an inadequate one in which the remnants of "free ride" has still not disappeared, and from the other extreme, it is attacked as pointing to the direction of becoming a "big military power." Where does the truth lie?

First of all, the change in Japan's defense budget from the latter 1960s is as follows:

In addition, according to Militaly Balance: 1982-83 Japan's defense ex-

\section{World's Ten Biggest Defense Spenders}

(Defense expenditures in US\$ million; per capita expenditures in US\$)

\begin{tabular}{|c|c|c|c|c|c|c|c|c|c|c|}
\hline & \multicolumn{5}{|c|}{ FY 1980} & \multicolumn{5}{|c|}{ FY 1981} \\
\hline Country & $\begin{array}{l}\text { Defense } \\
\text { expendi- } \\
\text { tures }\end{array}$ & $\begin{array}{l}\text { Share of } \\
\text { total } \\
\text { budget } \\
\text { expendi- } \\
\text { tures }\end{array}$ & $\begin{array}{l}\text { Ratio } \\
\text { to } \\
\text { GNP }\end{array}$ & $\begin{array}{c}\text { Per } \\
\text { capita } \\
\text { expendi- } \\
\text { tures }\end{array}$ & $\begin{array}{l}\text { Ranking } \\
\text { (esti- } \\
\text { mated) }\end{array}$ & $\begin{array}{l}\text { Defense } \\
\text { expendi- } \\
\text { tures }\end{array}$ & $\begin{array}{l}\text { Share of } \\
\text { total } \\
\text { budget } \\
\text { expendi- } \\
\text { tures }\end{array}$ & $\begin{array}{l}\text { Ratio } \\
\text { to } \\
\text { GNP }\end{array}$ & $\begin{array}{c}\text { Per } \\
\text { capita } \\
\text { expendi- } \\
\text { tures }\end{array}$ & $\begin{array}{l}\text { Ranking } \\
\text { (esti- } \\
\text { mated) }\end{array}$ \\
\hline & & $\%$ & $\%$ & & & & $\%$ & $\%$ & & \\
\hline USSR & - & - & - & - & 1 & - & - & 15 & - & 1 \\
\hline $\begin{array}{l}\text { United } \\
\text { States. }\end{array}$ & 142,200 & 23.6 & & 644 & 2 & 176,100 & 25.3 & 6.1 & 782 & 2 \\
\hline China & - & 一 & - & - & 3 & - & - & - & - & 3 \\
\hline $\begin{array}{r}\text { Germany, } \\
\text { F.R. }\end{array}$ & 33,611 & 28.3 & - & 548 & 4 & 29,047 & 28.2 & 4.3 & 471 & 4 \\
\hline Saudi & 20,766 & 28.1 & - & 2,525 & 7 & 24,417 & 27.7 & 20.5 & 3,014 & 5 \\
\hline $\mathrm{U} . \mathrm{K}$. & 25,921 & 10.7 & - & 463 & 6 & 24,223 & 12.1 & 5.4 & 433 & 6 \\
\hline France & 26,067 & 19.5 & - & 483 & 5 & 23,545 & 20.7 & 4.1 & 437 & 7 \\
\hline Japan & 12,637 & 5.8 & $(0.9)$ & 108 & 8 & 10,453 & 4.8 & 0.9 & 89 & 8 \\
\hline Argentia & 3,060 & 9.7 & - & 113 & - & 10,084 & 15.1 & 8.1 & 360 & 9 \\
\hline Italy & 9,579 & 5.4 & - & 168 & 9 & 8,769 & 5.6 & 2.5 & 153 & 10 \\
\hline
\end{tabular}

Source: The Military Balance 1982-1983, International Institute for Strategic Studies, London.

Notes: (1) To facilitate comparison, each country's defense expenditures are converted into U.S. dollars computed according to the average exchange rate for the fiscal year. (In the case of Japan, the yen rate per dollar was $¥ 176.48$ for 1980 and $¥ 229.59$ for 1981.)

(2) Although The Military Balance places Japan's defense spending in 1980 and 1982 at $5.8 \%$ and $4.8 \%$ of budget expenditures respectively, defense spending was actually $5.2 \%$ and $5.1 \%$. 
penditure is presently the eighth largest in the world.

Now, if we follow our "comprehensive security" concept in order to ascertain Japan's security, the efforts in the military domain and the efforts in the non-military domain should be carried forth in a well-balanced form. However, the concept does not negate that the basis of security lies first in the aspect of military defense.

The two pillars of Japan's military security has been, are, and will be:

(1) the build-up of defense capabilities of Japan itself.

(2) the maintenance of Japan-U.S. Security Treaty.

It seems to be nearly impossible for Japan to rely on herself alone for security even from an economic viewpoint. But even if this is possible, her relations with the United States and Asian-Pacific countries will deteriorate and the fear will grow that Japan will be internationally isolated, provided Japan is to possess large scale defense force on its own. This in turn would make the assurance of Japan's security more difficult.

The options Japan has consistently pursued since the Pacific War are as follows:

(1) In the political scene, Japan has been setting liberal democracy as the most important and basic value.

(2) In the economic scene, Japan has been aiming at prosperity and stability in the free and open international economic trade system.

(3) In the military scene, Japan has been a pacifist country concentrating on self-defense and non-offensive defense and avoiding the course of a great military power.

These options eventually mean that Japan's national interest is closely linked to that of the Western nations as a whole, including the U. S., Europe, and Oceania and that in circumstances relating to the security of the entire 


\section{Japan's Security and the International Environment (Kamiya)}

Western society Japan should act in solidarity and cooperation with them. Therefore, Japan must make further efforts in contributing to the formulation of policies of the entire Western world and pay her fair share of cost, carrying out her responsibility and playing her role in the future. The cooperation and burden-sharing with the United States is particularly important.

\section{Defense Efforts in Fiscal 1983}

Let me finally explain Japan's defense efforts in fiscal 1983. Responding to Prime Minister Nakasone's basic policy of stressing the importance of defense and close cooperation with the United States, Japan's ultra-austere budget for the current fiscal year gives top priority to expanded defense spending, with rigorous curbs on outlays for social security and other domestic spending. There is no increase in the government's general expenditure over the current fiscal year, so the increase in defense spending is met by decreasing other items.

Defense spending in the new budget will rise $6.5 \%$ over the previous year. This appears less than the $7.8 \%$ increase in the fiscal 1982, but this is misleading, since the last budget included pay raises for the SelfDefense Agency, whereas the fiscal 1983 does not. Without thses pay increases, the 1982 budget would have shown an increase of $5.4 \%$, contrasted with current year's increase of $6.5 \%$.

The new budget is notable for a substantial increase of $21.2 \%$ in outlays for front-line equipment such as F-15 and P-3C, tanks, warships, helicopters, artillery, and so on. This is nearly twice the rate of increase of the previous year. In addition, Japan's contributions to improving facilities used by U.S. Forces in Japan will be raised by $24.8 \%$.

At Japan's low level of inflation, $6.5 \%$ increase in defense spending will 
amount to real growth of $4.3 \%$, substantially higher than the $3 \%$ rise targeted by the NATO countries for defense spending. Moreover, the share of defense spending in the government's general expenditures has risen from $7.3 \%$ in 1980 to $7.9 \%$ in 1982 to $8.4 \%$ for this fiscal year. As a percentage of GNP, the new budget ratio of defense spending will be $0.98 \%$.

Comparison of defense spending with other major items in the new budget is striding. Total government expenditure will show a zero increase, while social security will rise $0.6 \%$, public works will register a zero increase, and education spending will decline by $0.9 \%$. Foreign economic assistance, on the other hand, which Japan considers an important element in the comprehensive security, will rise $7 \%$ with Official Development Assistance up $8.9 \%$.

\section{FY83 Defense Budget of Japan}

(billion yen)

1. Highest priority was given to the defense expenditure under the extremely serious fiscal austerity.

(1) There will be no increase in General Expenditure. Increase in the defense expenditure will be met by decrease in other items.

\begin{tabular}{|c|c|c|r|r|}
\hline & 1980 & 1981 & 1982 & 1983 \\
\hline (a) $\begin{array}{l}\text { Increase in General } \\
\text { Expenditure }\end{array}$ & $1,499.6$ & $1,317.2$ & 569.6 & -0.5 \\
\hline \begin{tabular}{l} 
(b) $\begin{array}{l}\text { Increase in defense } \\
\text { expenditure }\end{array}$ \\
\hline (c) Increase in other items
\end{tabular} & 135.7 & 169.8 & 186.1 & 168.1 \\
\hline \multicolumn{1}{|c|}{ (b) / (a) (\%) } & 9.0 & 12.0 & 32.7 & 168.1 \\
\hline
\end{tabular}

(2) Share of defense spending in the General Expenditure has been increased steadily. 
Japan's Security and the International Environment (Kamiya)

\begin{tabular}{|l|c|c|c|c|}
\hline & 1980 & 1981 & 1982 & 1983 \\
\hline $\begin{array}{l}\text { Increase rate of General } \\
\text { Expenditure }\end{array}$ & 5.1 & 4.3 & 1.8 & 0 \\
\hline $\begin{array}{l}\text { Increase rate of defense } \\
\text { expenditure }\end{array}$ & 6.5 & 7.6 & 7.8 & 6.5 \\
\hline $\begin{array}{c}\text { Share of defense expenditure } \\
\text { in General Expenditure (\%) }\end{array}$ & 7.3 & 7.5 & 7.9 & 8.4 \\
\hline
\end{tabular}

(3) Among the four major items, defense is given by far the highest increase rate.

\begin{tabular}{|lc|c|c|c|c|}
\hline & & 1980 & 1981 & 1982 & 1983 \\
\hline Social Welfare & $(\%)$ & 7.7 & 7.6 & 2.3 & 0.6 \\
\hline Education & $(\%)$ & 5.2 & 4.8 & 2.6 & -0.9 \\
\hline Public Works & $(\%)$ & 1.7 & 0 & 0 & 0 \\
\hline ODA & $(\%)$ & & & & 8.9 \\
\hline
\end{tabular}

2. Maximum efforts to improve Japan's self-defense capabilites was made. It is to be noted that the cost-of-living-adjustment (wage increase) is not included in FY '83 draft budget, because the Government has decided to freeze the salaries in the face of budgetary deficit despite the recommendation by the National Personnel Authority to raise them.

(1) Increase rate of defense expenditure without counting wage increase (Operation and Maintenance, Procurement, Military Construction, etc.)

\begin{tabular}{|l|c|c|c|c|}
\hline & 1980 & 1981 & 1982 & 1983 \\
\hline Defense Expenditures & $2,230.2$ & $2,400.0$ & $2,586.1$ & $2,754.2$ \\
\hline Increasing rate $(\%)$ & 6.9 & 7.6 & 7.8 & 6.5 \\
\hline $\begin{array}{l}\text { Increase rate without wage } \\
\text { increase }\end{array}$ & 4.7 & 5.5 & 5.4 & 6.5 \\
\hline
\end{tabular}

(2) The ratio of the defense expenditure to the GNP has been steadily increasing.

\begin{tabular}{|l|l|l|l|l|}
\hline & 1980 & 1981 & 1982 & 1983 \\
\hline Ratio of defense expenditure & 0.90 & 0.91 & 0.93 & 0.98 \\
\hline
\end{tabular}


Japan is thus making efforts today to build up its defense force which have up to this point been far too inadequate. Neverthless, I would like to repeat that we never intend to mold Japan into a big military power. Japan's defense plan, persistently based on the Security Pact with the U.S. is to counter:

(1) limited and small scale aggression with Japan's self-defense forces,

(2) large scale conventional invasion with our self-defense forces plus U.S. cooperation under the Japan-U.S. security system,

(3) and nuclear threat with the nuclear umbrella provided by the United States.

Our basic defense policy is to stick to the concept of the non-offensive defense under the peace constitution, without becoming a big military power, and to follow the "Three Non-Nuclear Principles" as the guideline of government. Our aim is to continue our efforts with a long-term perspective while searching for a national consensus. And, for the time being, it is an urgent necessity to achieve the standard set in "the National Defense Program Outline" decided in 1976 for the five years: FY 1983-87. But in reality, the actual situation is that while the United States is demanding its attainment ahead of schedule, Japan's present budgetary size makes the attainment of the goals within the schedule rather difficult. Therefore, the "defense friction" between Japan and the United States is not likely to dissolve easily for some time. In other words, it can be said that our defense policy's problems lies in the fear of not being able to accomplish enough to satisfy the United States rather than in the fear of superfluous defense efforts.

After all, Japan's defense capability in the 1980 seem to continuously show gradual increase in the middle-road framework that I have been 
Japan's Security and the International Environment (Kamiya)

describing. In contrast to such an opinion assumed by the majority, there are, on the one hand, believer of a more self-assertive nationalistic posture who claim that Japan should revise its constitution and the Japan-U.S. Security Tready so as to become more "autonomous" militarily. And on the other hand, not a few Japanese worry about the Reagan administration's attitude which gives priority to military build-up in order to meet the Soviet challenge, and oppose the Japanese government's move to follow it. They agree to the approach of the "carrot" and the "stick" to counter the Soviet Union, but they fear that Reagan's policy apparently lacks the "carrot." These people, for example, think negatively of the question of defending sea lane to the extent of 1000 nautical miles south of Japan for the reason that this signifies a commitment to a "regional defense" beyond the framework of "self-defense." Despite these criticisms from both sides, I believe that the middle-road framework will not relinguish its position as the majority in the foreseeable future. Provided that such a situation is to occur, it could only possible in such situation as the collapse of the free trade principle in the world and the international domination of protectionism. 